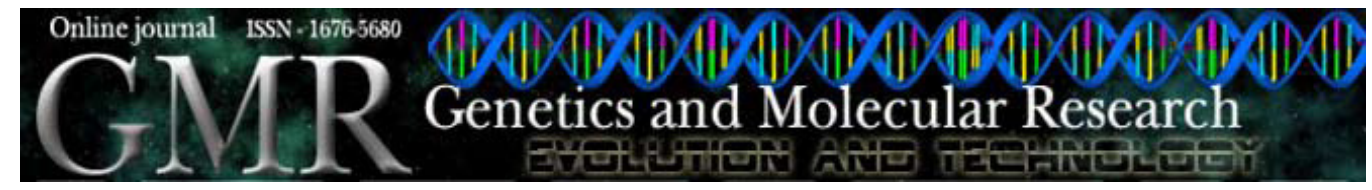

\title{
A mixed colony of Scaptotrigona depilis and Nannotrigona testaceicornis (Hymenoptera, Apidae, Meliponina)
}

\author{
C. Menezes ${ }^{1}$, M. Hrncir ${ }^{2}$ and W.E. Kerr ${ }^{3}$ \\ ${ }^{1}$ Departamento de Biologia, Faculdade de Filosofia, \\ Ciências e Letras de Ribeirão Preto, \\ Universidade de São Paulo, Ribeirão Preto, SP, Brasil \\ ${ }^{2}$ Departamento de Biologia, Faculdade de Filosofia, \\ Ciências e Letras de Ribeirão Preto, \\ Universidade de São Paulo, Ribeirão Preto, SP, Brasil \\ ${ }^{3}$ Instituto de Genética e Bioquímica, Universidade Federal de Uberlândia, \\ Instituto de Genética e Bioquímica, Uberlândia, MG, Brasil \\ Corresponding author: C. Menezes \\ E-mail: menezes.cristiano@gmail.com
}

Genet. Mol. Res. 8 (2): 507-514 (2009)

Received December 12, 2008

Accepted January 26, 2009

Published May 12, 2009

\begin{abstract}
We describe a case of a spontaneously established mixed colony of two species of stingless bees. The host colony of Scaptotrigona depilis, an aggressive bee that forms large colonies, was invaded by workers of Nannotrigona testaceicornis, a smaller bee that forms small colonies. The host colony and the invading species colony were maintained in next boxes about $1.5 \mathrm{~m}$ apart. The $N$. testaceicornis colony had been recently divided. Observations were made daily for $10 \mathrm{~min}$, and every two weeks the colony was opened for observations within the nest. Initially the host colony bees repulsed the invading species, but as their numbers built up, they were no longer able to defend the entrance. An estimated 60-90 N. testaceicornis workers lived integrated into the colony of S. depilis for 58 days. During this period, they reconstructed and maintained the entrance
\end{abstract}


tube, changing it to an entrance typical of $N$. testaceicornis. They also collected food and building material for the host colony. Nannotrigona testaceicornis tolerated transit of $S$. depilis through the entrance, but did not allow the host species to remain within the tube, though the attacks never resulted in bee mortality. Aggression was limited to biting the wings; when the bees fell to the ground they immediately separated and flew back. There have been very few reports of spontaneously occurring mixed stingless bee colonies. It is difficult to determine what caused the association that we found; probably workers of $N$. testaceicornis got lost when we split their colony, and then they invaded the colony of S. depilis.

Key words: Stingless bees; Behavior; Communication; Mixed colony; Nestmate recognition

\section{INTRODUCTION}

Mixed colonies represent a form of interaction between social organisms, in which one species participates in the social organization of another species (Nogueira-Neto, 1950; Michener, 1974). Since the beginning of the last century, artificially formed mixed colonies have been used for bionomics studies in ants (Forel, 1923 apud Nogueira-Neto, 1950; Carlin and Hölldobler, 1983; Errard, 1984; Vienne et al., 1992), termites (Dropkin, 1946) and bees (Plath, 1934; Munakata and Sakagami, 1958; Tan et al., 2006).

Kerr (1948 apud Nogueira-Neto, 1950) was the first to produce such artificial mixed colonies in stingless bees, joining two species of the genus Melipona. Thereafter, Nogueira-Neto (1950) and Silva (1977) performed extensive studies on this subject and Juliani (1967), Rezende (1967) and Oliveira and Imperatriz-Fonseca (1973) used this technique to study the bionomics of stingless bees of the genus Plebeia, focusing on the provisioning and oviposition process.

Mixed colonies also occur naturally, as has been observed in some species of ants (King and Sallee, 1959; Czechowski, 2001) and bumblebees (Michener, 1974). In stingless bees, a single case of a natural mixed colony has been described so far (Roubik, 1981). The other cases that formed spontaneously did not occur in natural nests, but in colonies kept in nest boxes where they are constantly disturbed by management (Nogueira-Neto, 1950; Pianaro et al., 2007). Therefore, the latter cases are considered as spontaneous mixed colonies, but not as natural mixed colonies. The "spontaneous" term means that the association was not formed artificially, as in the events reported by Kerr, 1948 apud Nogueira-Neto, 1950 and Silva (1977). On the other hand, our colony may also not be natural because human disturbance could have caused this situation. We describe the case of a mixed colony, which formed spontaneously between the species Scaptotrigona depilis Moure, 1942, and Nannotrigona testaceicornis Lepeletier, 1836. Scaptotrigona depilis is a small- to medium-sized bee that is very aggressive; if disturbed, it will attack a person 2 $\mathrm{m}$ from the colony. During the attack, the bees entangle in the hair of the disturber and bite him with their mandibles. The colonies of $S$. depilis are very populous, ranging from 2000 to 50,000 individuals (Lindauer and Kerr, 1960). Nests are built in already-existing cavities, usually inside trees. Nannotrigona testaceicornis, on the other hand, is a small and 
unaggressive species; the workers hide when are disturbed. The populations of colonies of N. testaceicornis range from 2000 to 3000 individuals (Lindauer and Kerr, 1960), and nests are built within already existing cavities, similar to $S$. depilis. Both these bee species are commonly found in urban environments of Southeastern Brazil (Souza et al., 2002).

\section{MATERIAL AND METHODS}

The host colony of $S$. depilis was invaded by workers of $N$. testaceicornis between July and September 2005, at Uberlândia, MG, Brazil. This colony was kept in a nest box about $1.5 \mathrm{~m}$ from a colony of $N$. testaceicornis that had been divided one week prior to the beginning of the invasion. This colony was kept in a nest box and was strong, based on the intense foraging activity and the quantity of stored food. At a distance of about $1.5 \mathrm{~m}$ from the $S$. depilis colony, a colony of $N$. testaceicornis had been split one week prior to the beginning of the invasion. The mother colony of $N$. testaceicornis, containing the physogastric queen, the young bees and all the original structure (new combs, food pots and cerumen), was carried to a distant place (about $30 \mathrm{~m}$ away). The new colony of $N$. testaceicornis was placed at the mother colony's location. It received foragers, four old combs with two royal cells and a few food pots removed from the mother colony. This recently founded colony was fed weekly with $50 \%$ sucrose solution. There was no other colony of $N$. testaceicornis in the area.

The formation of the mixed colony was accompanied from the beginning of its establishment until the end of this association. The presence of an observer or a video camera strongly interfered in the bees' behavior; after a short period the $S$. depilis workers started to attack the observer (or the camera) and the workers of $N$. testaceicornis hid inside the entrance tube of the nest. Due to this fact, the observations were interrupted as soon as such a disturbance occurred. Observations were made daily for a total of $10 \mathrm{~min}$ per day, divided into irregular intervals due to the reasons explained above. Every two weeks, the hive was opened for observations within the colony.

\section{RESULTS}

\section{External observations}

Initially, about four to eight workers of $N$. testaceicornis were seen trying to enter the $S$. depilis colony, but they were fended off by the guards, which tried to bite the invaders. During the subsequent three days, the number of invaders increased to approximately 25 bees. Gradually, they occupied the entrance tube because the defending workers could no longer repel all the invaders. Although we observed aggressive actions of $S$. depilis workers towards the invading $N$. testaceicornis individuals at the beginning of the invasion, no bees of either species died.

During the time that the mixed colony existed, the $N$. testaceicornis workers occupied the entrance tube. However, they allowed a normal flow of foragers of both S. depilis and $N$. testaceicornis. Aggressive interactions between the species were observed only when workers of $S$. depilis tried to remain in the entrance tube (Figure 1). On these occasions, the S. depilis workers were bitten on the wings by the $N$. testaceicornis workers. Generally, the fighting workers fell out of the entrance tube and untangled immediately. 


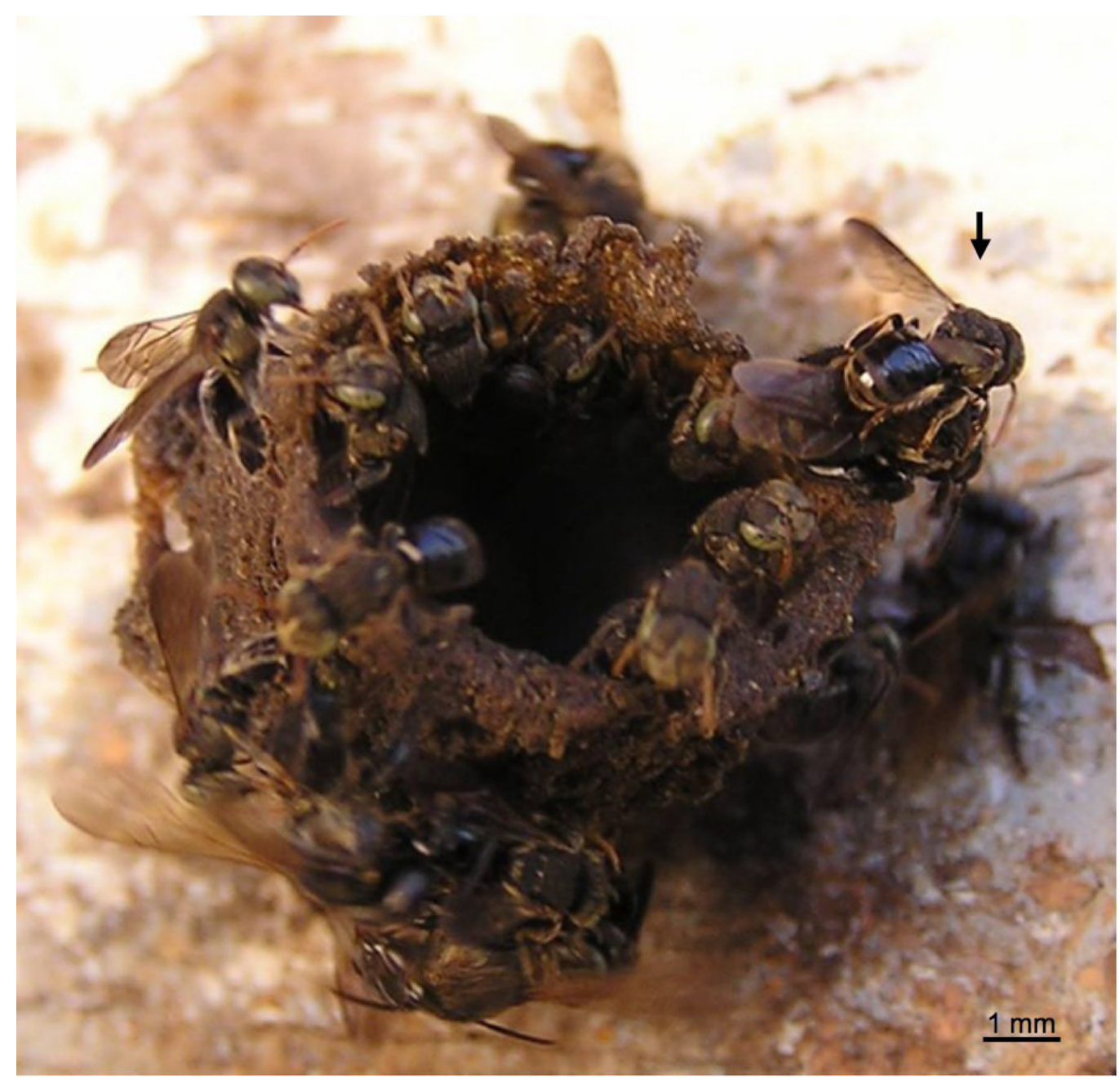

Figure 1. Entrance tube of the mixed colony during the day. The arrow indicates a worker of Nannotrigona testaceicornis biting a worker of Scaptotrigona depilis that tried to stay in the entrance tube.

From the beginning of the association, the only species that worked on the entrance tube was $N$. testaceicornis. The cerumen of $S$. depilis was replaced by cerumen produced by $N$. testaceicornis. After a few days the entrance tube had all the characteristics of a typical $N$. testaceicornis nest-entrance: a lighter-colored cerumen with small perforations and a soft texture. During the night, the tube was closed, which is also an attribute of $N$. testaceicornis and uncommon in S. depilis (Figure 2). At sunrise, workers of $N$. testaceicornis opened the entrance tube and occupied it. Some workers of this species were also observed to forage for food (pollen and nectar) and for building materials (resins) and to remove debris. 


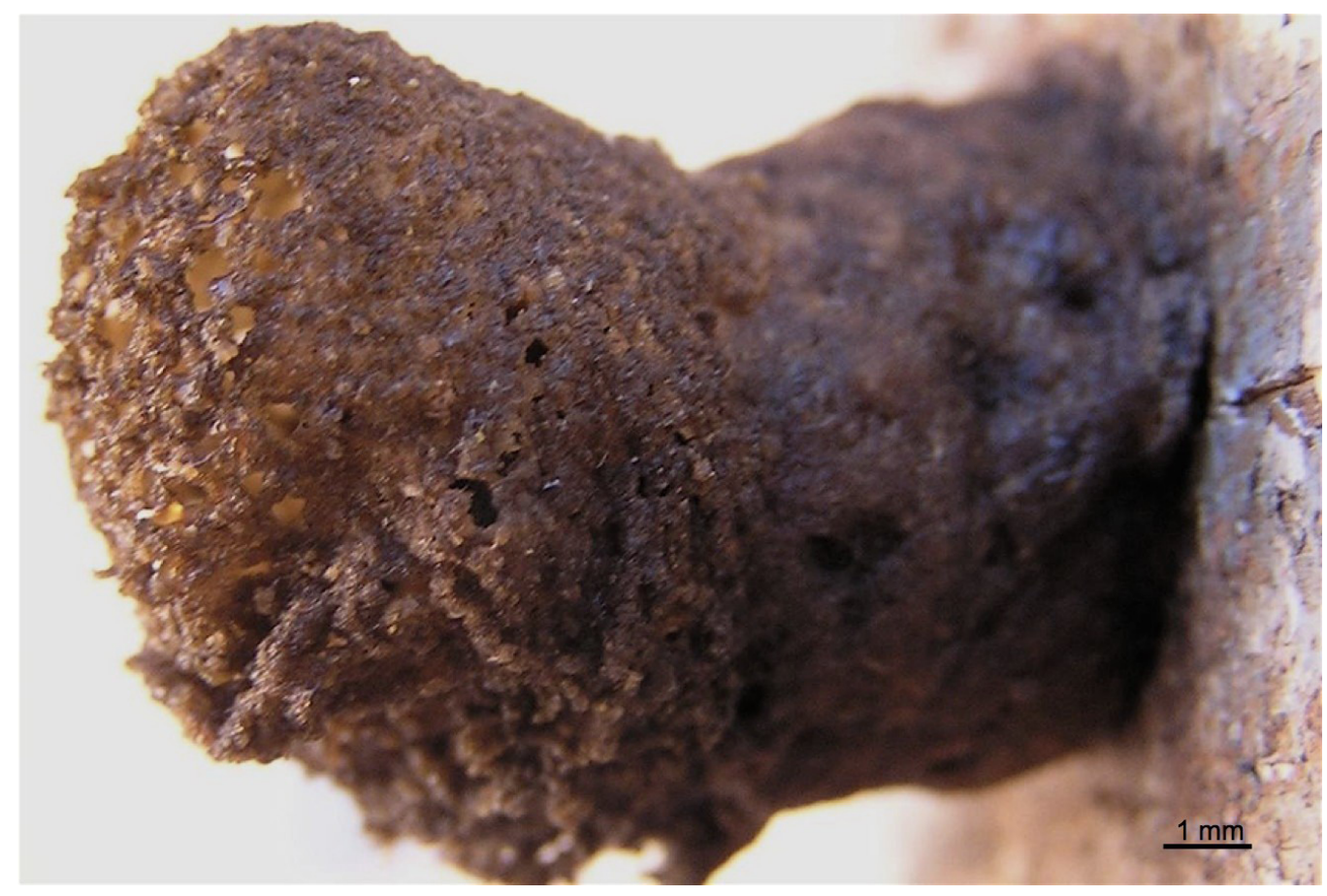

Figure 2. Entrance tube of the mixed colony during the night. Workers of Nannotrigona testaceicornis closed it with cerumen. Note the small perforations in the cerumen, characteristic of $N$. testaceicornis entrance tubes.

\section{Internal observations}

Despite the presence of $N$. testaceicornis workers inside the colony, the internal nest architecture was kept intact, and $S$. depilis workers behaved normally. Whenever the nest was opened, the workers of $S$. depilis became very excited and attacked the observer. But even in this situation, there was no aggressive behavior towards the invaders. Both bee species used the same storage pots, which had size and cerumen characteristic for $S$. depilis. Workers of $N$. testaceicornis were seen depositing food into the pots without aggressive interactions between the species. Sometimes, even trophallactic food exchange between workers of the different species could be observed. Right after opening the hive, no workers of $N$. testaceicornis could be seen on the combs. The involucrum, which encloses the comb region, was disrupted by the opening of the nest box. After a while, workers of $N$. testaceicornis were observed to crawl onto the recently built combs where they sometimes tried to bite the physogastric queen of $S$. depilis, but they never actually did. These biting attempts did not affect the queen; she would quickly retreat to the bottom of the nest. This behavior was registered three times and based on the damaged wings of the queen, we concluded that the queen was not replaced during the observation period. The workers of S. depilis also showed no aggressive reactions during these biting incidents. 
About two months after the establishment of the mixed colony, the number of workers of $N$. testaceicornis gradually diminished; though they were not aggressively expelled by $S$. depilis. The entire interaction lasted for 58 days, counted from the first day workers of $N$. testaceicornis were seen at the entrance tube of $S$. depilis until the day no more invaders could be seen in the host colony. Based on the number of bees counted in the entrance tube and inside the hive, between 60 and 90 workers of $N$. testaceicornis invaded the colony of $S$. depilis. No queens nor males of $N$. testaceicornis were observed inside the host nest or in its surroundings. After the end of the association, three other attempts of invasion by four to eight workers of $N$. testaceicornis were observed, but they failed. The two colonies of $N$. testaceicornis did not change much during this period. The old colony remained strong after splitting. Gradually, the new colony, which stayed at the original place, became stronger; five weeks after the splitting, a physogastric queen was seen inside the nest. The colony of $S$. depilis remained strong and the queen was not replaced during our observations.

\section{DISCUSSION}

In his study on artificially mixed colonies, Nogueira-Neto (1950) concluded that the tolerance level between two different species is not correlated with their phylogenetic relationship, as he found cases of high aggressiveness between species of the same genus, as well as cases of low aggressiveness between phylogenetically distant species. However, the experimental conditions varied a lot from one mixed colony to another. Other variables, such as the presence or absence of a queen in the colony, could have interfered with the results. Evidence for the importance of the phylogenetic relationship for mixed colonies is given by Oliveira and Imperatriz-Fonseca (1973). They showed that a colony of Plebeia saiqui accepted combs of $P$. droryana, but rejected combs of $P$. remota and $N$. testaceicornis. According to the molecular phylogeny proposed by Costa et al. (2003), $P$. saiqui is more closely related to $P$. droryana than to the other two species. In addition, most cases of mixed colonies that formed spontaneously also occurred between closely related species: Melipona flavipennis and M. fasciata (Roubik, 1981); M. scutellaris and M. rufiventris (Pianaro et al., 2007); Trigona pallens and T. fulviventris (Mateus S, unpublished data). Apart from the present study, only a single reported case involves bee species from two different genera, Plebeia mosquito and Friesella schrottkyi (Nogueira-Neto, 1950). However, according to the phylogeny proposed by Michener (1990), these genera are closely related. Therefore, we conclude that the probability of forming mixed colonies between two species increases with the degree of their phylogenetic relationship.

Studies on the phylogenetic relationship between Scaptotrigona and Nannotrigona are contradictory. Although some authors, based on morphological characteristics, concluded that the relationship between these two bee genera is very close (Michener, 1990; de Camargo and de Menezes Pedro, 1992), phylogenetic studies based on molecular data point to the contrary (Costa et al., 2003). In addition to the morphological characters shared by these two bee genera (Michener, 2000), some chemical features are common to both Scaptotrigona and Nannotrigona. Hartfelder and Engels (1989) showed that the general composition of the larval food of these genera is very similar when compared to other genera. Furthermore, pollination of the orchid Mormolyca rigens by males of both genera through pseudo-copulation indicates that the pheromones involved in the attraction of the males are similar (Singer et al., 2004; Flach et al., 2006). These facts point to the possibility that Scaptotrigona and Nannotrigona 
use similar chemical substances for communication. This could explain the observed tolerance between workers of these two species in the mixed colony. However, reactions against an invader sometimes are not evidenced by obvious aggressive behavior, but can be expressed in a "chemical war", which is invisible to the observer (Pianaro et al., 2007).

Silva (1977) formed artificial mixed colonies of S. postica and N. testaceicornis, introducing various elements of a colony into the nest of the other species, including physogastric queens and combs. Four of six assays were not successful and two were only partially successful. Apparently, these species do not tolerate each other when a queen or a comb is exchanged. This could explain our observations that workers of $N$. testaceicornis tried to bite the physogastric queen.

Jungnickel et al. (2004) gave an explanation for the difficulties of the guard bees to quickly recognize invading foragers. Invader workers arriving from the field land very quickly, in most cases carrying nectar, pollen or resins. The mixture of odors increases the difficulty for the guard bee to recognize an invader bee. Many invaders even perform trophallaxis with individuals of the host colony, which raises their possibility of being accepted by the hosts (Roubik, 1981). This may explain why the foragers of $N$. testaceicornis were accepted in the invaded colony.

As long as the mixed colony of $N$. testaceicornis and $S$. depilis remained, neither queens nor males of $N$. testaceicornis were observed inside the host nest or nearby. Consequently, it can be assumed that it was not a swarm. Based on our observations of this colony and on the facts discussed above, we suggest that mixed colonies are formed due to a recognition error made by both species involved. Invading workers might have become lost because of some disturbance at the original nest entrance. In this case, the disturbance was the splitting of the $N$. testaceicornis nest. Subsequently, the foragers confounded the original nest entrance with the entrance of another nest, due to its proximity but also due to physical and chemical similarities with the original entrance. Initially, rejection by the guard bees was observed. Gradually, however, the chemical characteristics of the invaders might have changed due to physical contact with the cerumen of the entrance tube and with other elements of the nest (Breed et al., 1988, 1995). Hence, they may not be recognized as an invader any more. On the other hand, the invaders recognize the nest as their own nest and start working on it. If the flow of invading workers from the original nest to the host nest ceases, this association finishes when all invaders have died.

\section{ACKNOWLEDGMENTS}

We thank the colleagues of São Paulo (IB-USP), Ribeirão Preto (FFCLRP-USP) and Uberlândia (INGEB-UFU) for valuable suggestions. We also thank Fundação de Amparo à Pesquisa do Estado de São Paulo (FAPESP) and Conselho Nacional de Desenvolvimento Científico e Tecnológico $(\mathrm{CNPq})$ for grants, which made this contribution possible (M. Hrncir, FAPESP, \#06/53839-4; C. Menezes, CNPq, \#142319/2006-6 and FAPESP, \#07/50218-1).

\section{REFERENCES}

Breed MD, Williams KR and Fewell JH (1988). Comb wax mediates the acquisition of nest-mate recognition cues in honey bees. Proc. Natl. Acad. Sci. U. S. A. 85: 8766-8769.

Genetics and Molecular Research 8 (2): 507-514 (2009) 
Breed MD, Garry MF, Pearce A, Hibbard BE, et al. (1995). The role of wax comb in honey bee nestmate recognition. Anim. Behav. 50: 489-496.

Carlin NF and Hölldobler B (1983). Nestmate and kin recognition in interspecific mixed colonies of ants. Science 222: 1027-1029.

Costa MA, Del-Lama MA, Melo GAR and Sheppard WS (2003). Molecular phylogeny of the stingless bees (Apidae, Apinae, Meliponini) inferred from mitochondrial 16S rDNA sequences. Apidologie 34: 73-84.

Czechowski W (2001). Mixed colony of Formica pratensis Retz. + Formica cinerea Mayr + Formica sanguinea Latr. (Hymenoptera: Formicidae) and its presumed origin. Ann. Zool. 51: 205-209.

de Camargo JMF and de Menezes Pedro SR (1992). Systematics, phylogeny and biogeography of the Meliponinae (Hymenoptera, Apidae): a mini-review. Apidologie 23: 509-523.

Dropkin VH (1946). The use of mixed colonies of termites in the study of host-symbiont relations. J. Parasitol. 32: 247-251.

Errard C (1984). Study of the social relationships in hetero-specific mixed colonies of ants as a function of age. Insectes Soc. 31: 185-198.

Flach A, Marsaioli AJ, Singer RB, Amaral MC, et al. (2006). Pollination by sexual mimicry in Mormolyca ringens: a floral chemistry that remarkably matches the pheromones of virgin queens of Scaptotrigona sp. J. Chem. Ecol. 32: 59-70.

Hartfelder K and Engels W (1989). The composition of larval food in stingless bees: evaluating nutritional balance by Chemosystematic methods. Insectes Soc. 36: 1-14.

Juliani L (1967). A descrição do ninho e alguns dados biológicos sobre a abelha Plebeia julianii Moure, 1962 (Hymenoptera, Apidae). Rev. Bras. Entomol. 12: 31-58.

Jungnickel H, da Costa AJ, Tentschert J, Patricio EF, et al. (2004). Chemical basis for inter-colonial aggression in the stingless bee Scaptotrigona bipunctata (Hymenoptera: Apidae). J. Insect Physiol. 50: 761-766.

King RL and Sallee RM (1959). Mixed colonies in ants. Anat. Rec. 134: 594.

Lindauer M and Kerr WE (1960). Communication between the workers of stingless bees. Bee World 41: 29-41, 65-71.

Michener CD (1974). The Social Behavior of the Bees: A Comparative Study. Harvard University Press, Cambridge.

Michener CD (1990). Classification of the Apidae (Hymenoptera). Univ. Kans. Sci. Bull. 54: 75-103.

Michener CD (2000). The Bees of the World. Johns Hopkins University Press, Baltimore.

Munakata M and Sakagami SF (1958). Zum Verfliegen der Hummeln unter den künstlich zusammengesetzten Völkchen. Kontyu 26: 15-19.

Nogueira-Neto P (1950). Notas bionômicas sobre meliponíneos. IV Colônias mistas e questões relacionadas. Rev. Bras. Entomol. 21: 305-367.

Oliveira MAC and Imperatriz-Fonseca VL (1973). Observações sobre o comportamento de uma colônia mista de Plebeia saiqui - Plebeia droryana (Hymenoptera, Apidae, Meliponinae). Ciênc. Cult. 25: 460-462.

Pianaro A, Flach A, Patricio EF, Nogueira-Neto P, et al. (2007). Chemical changes associated with the invasion of a Melipona scutellaris colony by Melipona rufiventris workers. J. Chem. Ecol. 33: 971-984.

Plath OE (1934). Bumblebees and Their Ways. MacMillan, New York.

Rezende JA (1967). Uma colônia mista de duas espécies de Plebeia (Hymenoptera, Apoidea). Papéis Avulsos Dept. Zool. 20: 9-12.

Roubik DW (1981). A natural mixed colony of Melipona (Hymenoptera: Apidae). J. Kansas Entomol. Soc. 54: 263-268.

Silva DLN (1977). Estudos bionômicos em colônias mistas de Meliponinae (Hymenoptera, Apoidea). Bol. Zool. Univ. S. Paulo 2: 7-106.

Singer RB, Flach A, Koehler S, Marsaioli AJ, et al. (2004). Sexual Mimicry in Mormolyca ringens (Lindl.) Schltr. (Orchidaceae: Maxillariinae). Ann. Bot. 93: 755-762.

Souza LA, Pereira TO, Prezoto F and Faria-Mucci GM (2002). Nest foundation and diversity of Meliponini (Hymenoptera, Apidae) in an urban area of the municipality of Juiz de Fora, MG, Brazil. Biosci. J. 18: 59-65.

Tan K, Hepburn HR, He SY, Radloff SE, et al. (2006). Gigantism in honeybees: Apis cerana queens reared in mixedspecies colonies. Naturwissenschaten 93: 315-320.

Vienne C, Errard C and Lenoir A (1992). Spatial-organization and nestmate recognition in artificial mixed colonies of Manica rubida and Myrmica rubra (Hymenoptera, Formicidae). Sociobiology 20: 1-16. 